\author{
Research Article \\ www.ijrap.net
}

\title{
ANTI-HYPERGLYCEMIC EFFECT OF ROOT POWDER OF COCCINIA GRANDIS L. VOIGT WITH SPECIAL REFERENCE TO MADHUMEHA: A PILOT STUDY
}

Vasavda Krup $^{1 *}$, Hegde Prakash L ${ }^{2}$, Harini A ${ }^{3}$ Mohammad Altaf ${ }^{4}$

${ }^{1}$ PG Scholar, Department of Dravyaguna, SDM College of Ayurveda and Hospital, Hassan, Karnataka, India

${ }^{2}$ Professor, Department of Dravyaguna, SDM College of Ayurveda and Hospital, Hassan, Karnataka, India

${ }^{3}$ Associate Professor, Department of Dravyaguna, SDM College of Ayurveda and Hospital, Hassan, Karnataka, India

${ }^{4}$ PG Scholar, Department of Swasthvritta, SDM College of Ayurveda and Hospital, Hassan, Karnataka, India

Received on: 12/09/14 Revised on: 03/10/14 Accepted on: 09/10/14

*Corresponding author

Dr. Krup S. Vasavda, PG Scholar, Department of Dravyaguna, Shri Dharmasthala Manjunatheshwara College of Ayurveda and Hospital, BM Road, Thanniruhalla, Hassan, Karnataka, India -573201 E-mail: krup1881@gmail.com

DOI: $10.7897 / 2277-4343.055123$

\section{ABSTRACT}

A clinical study was conducted on patients of Madumeha nearest resembling condition with diabetes mellitus, a rich man's disease to evaluate the hypoglycemic effect of root powder of Bimbi (Coccinia grandis L. Voigt) which traditionally practiced in rural areas of Kerala and Karnataka, India. On the basis of this survey, present study was designed on newly diagnosed cases of type II Diabetes mellitus. The aim and objectives of this study was to evaluate the hypoglycaemic effect of root powder of Bimbi (Coccinia grandis L. Voigt). This study was planned on 10 newly diagnosed cases of diabetes mellitus who was administered with root powder of Bimbi (Coccinia grandis L. Voigt), Result obtained from study revealed that root powder of Bimbi (Coccinia grandis L. Voigt) showed good effects in relieving the subjective criteria's viz. Prabhootamootrata, Kshudhadhikyata, Daurbalya and Pipasadhikyata. It has also shown significant result in objective criteria's like FBS, FUS, and PPUS.

Keywords: Bimbi, Coccinia grandis L. Voigt, Diabetes mellitus, Madhumeha

\section{INTRODUCTION}

Diabetes mellitus is the most severe metabolic pandemic of the $21^{\text {st }}$ century, affecting essential biochemical activities in almost every cell in the body and increasing the risk of cardiac problems. It is estimated that in the year 2000, 171 million people had diabetes and this is expected to double by year 2030. ${ }^{1}$ The disease Madhumeha, its definition, etiology, clinical features and principles of treatment appear to be similar with the disease "Diabetes mellitus", which is considered as "Ice Berg" disease in the present era. ${ }^{2}$ In conventional therapy, Type I diabetes is treated with exogenous insulin and Type 2 with oral hypoglycemic agents (sulphonylureas, biguanides etc). ${ }^{3}$ Though different types of oral hypoglycemic agents are available along with insulin for the treatment of diabetes, there is an increased demand by patients to use natural products with antidiabetic activity. ${ }^{4}$ The Indian subcontinent is enriched by a variety of floraboth aromatic and medicinal plants. This extensive flora has been greatly utilized as a source of many drugs in the Indian traditional system of medicine. ${ }^{5}$ Few researches have analyzed the efficacy of various Dravya's mentioned in Ayurvedic classics in Madhumeha. Here an attempt was made to analyze the effect of "Mula choorna (Root powder) of Coccinia grandis L. Voigt" which is used by many traditional practioners of Kerala and Karnataka, India. There is reference of use of Bimbi root powder in Bhavaprakash Nighantu ${ }^{6}$ which can be traced. The analysis of Mula choorna (Root powder) of the Coccinia grandis L. Voigt indicated the presence of alkaloid, amino acids, coumarin, terpenoid, tannin, phenol, steroid, carbohydrate / glycoside and flavonoids.

\section{Aims and Objectives}

To evaluate the efficacy of root powder of the Coccinia grandis L. Voigt in the management of Madhumeha with special reference to Diabetes mellitus

\section{MATARIALS AND METHODS \\ Source of Data}

Botanically identified genuine root of Bimbi (Coccinia grandis L. Voigt) belonging to Cucurbitaceae family was procured from Rayapura, Hassan district and authentified by Department of Dravyaguana SDM College of Ayurveda and Hospital, Hassan, Karnataka, India.

\section{Source of the Patients}

Patients were selected after subjecting them through clinical examination from OPD and IPD of SDM College of Ayurveda and Hospital, Hassan, Karnataka, India. Ethical clearance number for this study is SDMCAH/IEC/08/11-12.

\section{Preparation of Medicine}

A well identified root of Bimbi (Coccinia grandis L. voigt) from Rayapura, Hassan district, Karnataka, India was procured, powdered and filtered in \#32 sieve mesh. The sieve powder was shelved in air tight container till further use.

\section{Place of Work}

Medicine was prepared at Department of Rasa Sastra and Bhaishajya Kalpana department SDM College of Ayurveda and Hospital, Hassan, Karnataka, India. Clinical trial was conducted at SDM College of Ayurveda and Hospital, Hassan, Karnataka, India. 


\section{Method of Collection of Data}

Written and informed consent was taken. Based on the classical signs and symptoms of Madhumeha, the patients of both sexes between the age group 30-60 years were selected from the OPD and IPD of SDM College of Ayurveda and Hospital. Totally 11 patients were selected for study by purposive sampling method following inclusion and exclusion criteria.

\section{Research Design}

11 newly diagnosed cases of Madhumeha were selected and they were administered Bimbi mula choorna in the dose of 3 grams twice a day before food. Diet and exercise were strictly advised.

Duration of Treatment: Two months.

\section{Inclusion Criteria}

Patients between the ages 30 to 60 years of either gender irrespective of chronicity were taken. Specific biochemical investigation was done. Patients with Fasting Blood Sugar level between 120 to $180 \mathrm{mg} / \mathrm{dl}$ and Post Prandial Blood Sugar level between 160 to $280 \mathrm{mg} / \mathrm{dl}$ selected for the study. Patients who have discontinued hypoglycemic drugs and first time diagnosed were included.

\section{Exclusion criteria}

- Patients with type 1 Diabetes mellitus.

- Patients with type 2 Diabetes mellitus who are insulin dependent.

- Patients of Gestational Diabetes and Juvenile Diabetes.

- Age group of above 60 year and below 30 years.

- Patients with complications like cardiac disorder, diabetic foot, Nephropathy and other secondary complications.

\section{FBS}

- 70 to $120 \mathrm{mg} / \mathrm{dl}$ normal

- 121 to $170 \mathrm{mg} / \mathrm{dl}$ mild

- 171 to $220 \mathrm{mg} / \mathrm{dl}$ moderate

- 220 above severe

\section{Assessment Criteria}

Subjective Parameters

For the assessment of the subjective parameters scoring was given to all the signs and symptoms from Grade 0-3 according to the severity and was documented properly before treatment, and after 60 days of the treatment. Assessment was done based on the criteria with their scoring. (Table 1)

Table 1: Assessment Criteria with Scoring

\begin{tabular}{|c|c|c|c|}
\hline S. No. & Criteria & Details & Score \\
\hline \multirow[t]{4}{*}{1} & \multirow[t]{4}{*}{ Prabhoota Mootrataday (Polyuria) } & $3-5$ times per day & 0 \\
\hline & & $6-8$ times per day & 1 \\
\hline & & 9-11times per day & 2 \\
\hline & & More than 11 times per day & 3 \\
\hline \multirow[t]{4}{*}{2} & \multirow{4}{*}{$\begin{array}{l}\text { Avila Mootrata } \\
\text { (Turbidity) }\end{array}$} & Crystal clear fluid & 0 \\
\hline & & Turbidity visible & 1 \\
\hline & & Buffy & 2 \\
\hline & & Milky white & 3 \\
\hline \multirow[t]{4}{*}{3} & \multirow[t]{4}{*}{ Atitrushna (Polydypsia) } & $\begin{array}{c}\text { Feeling of thirst } 7-9 \text { times/24 hours, either/or Intake of water } 5-7 \text { times/24hours } \\
\text { with quantity } 1.5-2.0 \text { liter/24 hours }\end{array}$ & 0 \\
\hline & & $\begin{array}{c}\text { Feeling of thirst } 9-11 \text { times/24 hours, either/or Intake of water } 7 \text { - } 9 \text { times/24 } \\
\text { hours with quantity } 2.0-2.50 \text { liter/24 hours }\end{array}$ & 1 \\
\hline & & $\begin{array}{c}\text { Feeling of thirst } 11-13 \text { times/24 hours, either/or Intake of water } 9-11 \text { times/24 } \\
\text { hours with quantity } 2.50-3.00 \text { liter/24 hours }\end{array}$ & 2 \\
\hline & & $\begin{array}{c}\text { Feeling of thirst }>13 \text { times } / 24 \text { hours, either/or Intake of water }>11 \text { times/24 hours } \\
\text { with quantity } \\
>3.00 \text { liter/ } 24 \text { hours }\end{array}$ & 3 \\
\hline \multirow[t]{4}{*}{4} & \multirow{4}{*}{$\begin{array}{l}\text { Atikshuda } \\
\text { (Polyphagia) }\end{array}$} & Feels hunger at next Annakala only & 0 \\
\hline & & Feels hunger for once in between Annakala & 1 \\
\hline & & Feels hunger for more than twice in between Anna kala & 2 \\
\hline & & Feels hunger always & 3 \\
\hline \multirow[t]{4}{*}{5} & \multirow{4}{*}{$\begin{array}{l}\text { Kara Pada Daha (Burning } \\
\text { sensation in palms and sole) }\end{array}$} & No burning sensation in hands and feet & 0 \\
\hline & & Mild burning sensation in hands and feet & 1 \\
\hline & & Moderate burning sensation in hands and feet & 2 \\
\hline & & Severe burning sensation in hands and feet & 3 \\
\hline \multirow{4}{*}{6} & \multirow{4}{*}{$\begin{array}{l}\text { Angamarda } \\
\text { (Body pain) }\end{array}$} & Normal & 0 \\
\hline & & Mild & 1 \\
\hline & & Moderate & 2 \\
\hline & & Severe & 3 \\
\hline \multirow{4}{*}{7} & \multirow{4}{*}{$\begin{array}{l}\text { Dourbalya } \\
\text { (Weakness) }\end{array}$} & Can do routine exercise/work & 0 \\
\hline & & Can do moderate exercise with hesitancy & 1 \\
\hline & & Can do mild exercise only, with difficulty & 2 \\
\hline & & Cannot do mild exercise too & 3 \\
\hline
\end{tabular}




\section{Statistical Methods}

Statistical analysis was done using SPSS VER. 16. Eleven patients were taken for statistical analysis. Wilcoxon sign rank test was applied to analyze the significance of change in subjective parameters. Paired t test was applied for analyzing the significance of objective parameters.

\section{RESULTS}

Effect of Root Powder of the Coccinia grandis L. Voigt on the Patients of Madhumeha (NIDDM)

As mentioned above 11 patients were treated with mula choorna of Bimbi administered in the dose of 3 grams twice a day before food for two months.

\section{Paired t Test}

Table 2: Effect of Root Powder of Coccinia Grandis L. Voigt (Bimbi) for Objective Parameters

\begin{tabular}{|c|c|c|c|c|c|c|c|c|}
\hline $\begin{array}{c}\text { Signs and } \\
\text { Symptoms }\end{array}$ & Mean BT & Mean AT & MD & $\%$ of Change & SD ( $( \pm)$ & SE ( $( \pm)$ & $t^{*}$ & $\begin{array}{c}\text { p value } \\
\text { (Significance) }\end{array}$ \\
\hline F.B.S & 1.56 & 1.45 & 0.11 & $7.05 \%$ & 15.07 & 4.54 & 2.37 & 0.03 \\
\hline F.U.S & 0.70 & 0.25 & 0.45 & $64.28 \%$ & 0.53 & 0.16 & 2.82 & 0.01 \\
\hline P.P.B.S & 2.15 & 2.06 & 0.09 & $4.18 \%$ & 19.78 & 5.96 & 1.38 & 0.19 \\
\hline P.P.U.S & 0.97 & 0.47 & 0.50 & $51.54 \%$ & 0.64 & 0.19 & 2.58 & 0.02 \\
\hline
\end{tabular}

\section{Willcoxin Sign Rank Test}

Table 3: Effect of Root Powder of Coccinia Grandis L. Voigt (Bimbi) for Subjective Parameters

\begin{tabular}{|c|c|c|c|c|c|c|c|c|c|c|}
\hline \multirow[t]{2}{*}{ Parameter } & \multicolumn{3}{|c|}{ Negative ranks } & \multicolumn{3}{|c|}{ Positive ranks } & \multirow[t]{2}{*}{ Ties } & \multirow[t]{2}{*}{ Total } & \multirow{2}{*}{$\begin{array}{c}\mathbf{Z} \\
\text { Value }\end{array}$} & \multirow{2}{*}{$\begin{array}{c}\mathbf{P} \\
\text { value }\end{array}$} \\
\hline & $\mathbf{N}$ & MR & SR & $\mathbf{N}$ & MR & SR & & & & \\
\hline PrabhutaMootrata & 7 & 4.00 & 28.00 & 0 & 0.00 & 0.00 & 4 & 11 & 2.646 & 0.008 \\
\hline AvilMootrata & 3 & 2.00 & 6.00 & 0.00 & 0.00 & 0.00 & 8 & 11 & 1.732 & 0.803 \\
\hline Pipasadhikyata & 8 & 4.50 & 36.00 & 0.00 & 0.00 & 0.00 & 3 & 11 & 2.449 & 0.014 \\
\hline Kshudhadhikyata & 6 & 3.50 & 21.00 & 0.00 & 0.00 & 0.00 & 5 & 11 & 2.828 & 0.005 \\
\hline KarapadaDaha & 9 & 5.00 & 45.00 & 0.00 & 0.00 & 0.00 & 2 & 11 & 2.828 & 0.005 \\
\hline Dourbalya & 6 & 3.50 & 21.00 & 0.00 & 0.00 & 0.00 & 5 & 11 & 3.000 & 0.003 \\
\hline Angamarda & 8 & 4.50 & 36 & 0.00 & 0.00 & 0.00 & 3 & 11 & 2.449 & 0.014 \\
\hline
\end{tabular}

\section{DISCUSSION}

\section{Effect of therapy on subjective parameters}

Prabhutmootrata between day 1 and day 60 was reduced in 7 subjects which is significant $(\mathrm{Z}-2.646, \mathrm{p} 0.001)$, Avilmootrata between day 1 and day 60 was reduced in 3 subjects which is not significant $(Z-1.732, p$ 0.001), Pipasadhikyata between day 1 and day 60 was reduced in 8 subjects and which is significant ( $Z-2.449$, p 0.001), Kshudhadhikyata between day 1 and day 60 was reduced in 6 subjects which is significant ( $Z-2.828, p$ 0.001), Karapadadaha between day 1 and day 60 was reduced in 9 subjects which is significant ( $Z-2.828$, p 0.001), Dourbalya between day 1 and day 60 was reduced in 6 subjects which is significant $(Z-3.000, p$ 0.001) and Angamarda between day 1 and day 60 was reduced in 8 subjects which is significant ( $\mathrm{Z}-2.449, \mathrm{p} 0.001)$.

\section{Effect of therapy on objective parameters}

FBS reduced significantly with the $p$ value at 0.03 after a period of two months. FUS reduced significantly with the $p$ value at 0.01 after a period of two months. PPBS reduced significantly with the $\mathrm{p}$ value at 0.19 after a period of two months. PPUS reduced significantly with the $\mathrm{p}$ value at 0.02 after a period of two months. Madhumeha (Diabetes mellitus) is a common disorder prevailing in the society. It is a chronic illness that requires continuous medical care and patient selfmanagement, education to prevent acute complications and to reduce the risk of long-term complications. Although a number of studies had been conducted on Madhumeha with many formulations, still early diagnosis of this iceberg disease has found maximum focus in the recent days due to its high incidence as an etiology in cardiac deaths. The aim of the present pilot study was to evaluate anti hyperglycemic activity of Bimbi as mentioned in classical texts for its anti-diabetic properties. Bimbi possess Tikta, Katu Rasa (bitterpungent taste), Laghu, Rooksha guna (light and rough property) and Katu Vipaka. Tikta, Katu rasa mainly acts as Pitta-Kapha shamaka ${ }^{7}$, Meda, Kleda Upashoshana (dries up fat and moisture). Laghu, Rooksha guna produces lekhana (scraping), rookshana (drying) effect and pacifies Kapha. ${ }^{8}$ It has Usna Virya (hot potency) which pacifies Vata. It possesses opposite qualities to that of Kapha and Medas. Hence they act as Mehahara (anti diabetic) and pacify Kapha according to SamanyaVishesh Siddhanta (concept of similarity and dissimilarity). This Tridosha shamaka property (pacifying all three humors) of the drugs helped to correct the Dhatu dushti (vitiated tissues) and Srotodushti (vitiated channels) leading other normal functioning. Bimbi helps in maintaining the muscle tone of urinary bladder because it is one of the best Mootrasangrahaniya (Anti diuretics) drug hence it reduces Prabhoota Mootrata. Atitrushna which is dependent on Prabhootha Mootrata also subsides with it. ${ }^{9}$ Relief in Karapadadaha may be due to its Pitta Kapha Shamaka so Dahaprashaman action may occur. Neuroprotective effect of Bimbi might have also provided the relief in this manifestation. Kamble et al has mentioned dried extract $(500 \mathrm{mg} / \mathrm{kg}$, p.o. for 6 weeks), of plant exhibited anti-hyperglycemic activity in diabetic patients. Extract mimic insulin like activity and improved the functional status of enzymes in glycolytic pathway and lypolytic pathway. Bimbi ensues Sarvadhatuposhana (nourishes all tissues) because of 
this properties there by reduces Daurbalya. Madhumehahara property of Bimbi Mula helps in alleviating hyperglycemia. Both Medas and Kapha being the main entity of the Samprapti, thus by breaking the Samprapti (correcting the vitiation of Medas and Kapha) treats the disease. Hence Bimbi act as Mehaghna. In addition Acharya PV Sharma has mentioned its mula swarasa (root juice) in the treatment of Madhumeha. ${ }^{10}$

\section{CONCLUSION}

Madhumeha known as silent killer needs to be treated as early as possible to stop onset of complication. Bimbi (Coccinia grandis L. Voigt) a very easily available drug may be considered as a major drug to heal Madhumeha. Bimbi has improved quality of life to all the patients who have undergone clinical trial. Single drug treatment like Bimbi Mula Churna can prove to be boon to the wide population suffering from Diabetes mellitus comprising of Pathyakara Aahara-Vihara followed with regular practice of Yogasanas. This pilot study proves that Bimbi mula choorna is an efficient as well as an ideal drug for its potent Madhumehahara (Anti hyperglycemic) effect.

\section{REFERENCES}

1. Boon NA, Colledge NR, Walker BR. Davidson's principles and practice of medicine: Diabetes mellitus, $20^{\text {th }}$ ed. London: Elsevier Press; 2006. p. 805-847.

2. Acharya Agnivesha; Charaka Samhita; redacted by Charaka and Dridabala with Ayurveda Dipika Commentary by Chakrapani Dutta; edited by Vaidya Yadavji Trikamji Acharya; $4^{\text {th }}$ Edition. Varanasi: Chaukhambha Surabharathi Prakashana; 2001. p. 213.

3. Pepato MT, Mori DM, Baviera AM, Harami JB, Vendramini RC, Brunetti IL. Fruit of the Jambolan tree (Eugenia jambolana Lam.) and experimental diabetes. J Ethno pharmacol 2005; 96: 43-8. http://dx.doi.org/10.1016/j.jep.2004.07.029

4. Venkatesh S, Reddy GD, Reddy BM, Ramesh M, Apparao AV. Anti hyperglycemic activity of Carulluma attenuate. Fitoterapia 2003; 74: 274-9. http://dx.doi.org/10.1016/S0367-326X(03)000212

5. Krup V, Prakash LH, Harini A. Pharmacological Activities of Turmeric (Curcuma longa Linn): A Review. J Homeop Ayurv Med 2013; 2: 133.

6. Pandey GS, editor. Bhavpraakash Nighantu of Bhavamisra. Varanasi: Chaukhambha Bharti Academy; 2010. p. 674.

7. Sharma PV. Dravya Guna Vijnana Vol II. Varanasi: Chaukhambha Bharti Academy; 2006. p. 688.

8. Sastry JLN. Dravya Guna Vijnana Vol II. $2^{\text {nd }}$ ed. Varanasi: Chaukhambha Orientalia; 2005. p.789.

9. Sastry JLN. Dravya Guna Vijnana Vol II. $2^{\text {nd }}$ ed. Varanasi: Chaukhambha Orientalia; 2005. p.790.

10. Sharma PV. Dravya Guna Vijnana Vol II. Varanasi: Chaukhambha Bharti Academy; 2006. p. 689.

Cite this article as:

Vasavda Krup, Hegde Prakash L, Harini A, Mohammad Altaf. Antihyperglycemic effect of root powder of Coccinia grandis L. Voigt with special reference to Madhumeha: A pilot study. Int. J. Res. Ayurveda Pharm. 2014;5(5):605-608 http://dx.doi.org/10.7897/2277-4343.055123 